\title{
PEMBELAJARAN MATEMATIKA DENGAN STRATEGI THINK TALK WRITE (TTW) DALAM UPAYA MENINGKATKAN BERPIKIR KREATIF MATEMATIS SISWA
}

\author{
Lia Saniah ${ }^{1}$, Lamlam Patimah ${ }^{2}$ \\ 1,2Universitas Putra Indonesia (UNPI) Cianjur \\ 1iasaniah@unpi-cianjur.ac.id, 2 lamlampatimah@unpi-cianjur.ac.id
}

\begin{abstract}
ABSTRAK
Penelitian ini bertujuan untuk menganalisis kemampuan berpikir kreatif matematis siswa yang mendapat pembelajaran dengan strategi Think-Talk-Write (TTW) dan siswa yang mendapat pembelajaran konvensional. Selain ini juga bertujuan untuk mengetahui sikap siswa terhadap pembelajara dengan strategi Think-Talk-Write (TTW). Metode yang digunakan dalam penelitian ini adalah metode kuasi eksperimen dengan instrumen test kemampuan berpikir kreatif matematis siswa serta angket sikap. Teknis analisis data yang digunakan dalam pengujian hipotesisi adalah uji perbedaan dua rata-rata, sedangkan dalam pengujian angket skala sikap menggunakan perbandingan rata-rata skor subjek dengan nilai netral. Berdasarkan hasil penelitian dan analisis data yang diperoleh, kesimpulannya bahwa peningkatan kemampuan berpikir kreatif matematis siswayang mendapatkan pembelajaran dengan strategi Think-Talk-Write (TTW) lebih tinggi dari pada siswa yang mendapatkan pembelajaran secara konvensional. Sikap siswa menunjukan sikap positif terhadap pembelajaran dengan strategi Think-Talk-Write (TTW).
\end{abstract}

Kata kunci: Think-Talk-Write (TTW), Kemampuan kreatif matematis, sikap.

\section{PENDAHULUAN}

Pendidikan merupakan pembentukan karakter baik menyangkut daya pikir, daya intelektual maupun daya emosional, hal ini sesuai dengan Undang-undang tentang Sistem Pendidikan Nasional No. 20 Tahun 2003 yang menyatakan bahwa "Pendidikan Nasional berfungsi mengembangkan kemampuan dan bentuk watak serta peradaban bangsa, yang bermanfaat dalam rangka mencerdaskan kehidupan bangsa".1 Dengan demikian pembangunan di bidang pendidikan begitu penting artinya untuk mencapai taraf kemajuan di segala bidang. Berdasarkan tujuan pendidikan tersebut, dalam upaya mewujudkannya perlu disusun sebuah strategi pembelajaran matematika yang mampu mempersiapkan siswa untuk menghadapi perubahan kehidupan dalam dunia yang terus berkembang. Dengan demikian diharapkan melalui penyampaian materi dengan strategi yang tepat, nilai-nilai yang terkandung dalam pembelajaran matematika dapat tersampaikan dan diterima secara cepat oleh para siswa, akhirnya akan terbentuk siswa yang memiliki pola pikir yang sistematis, logis, kritis, kreatif dan terarah. Pola pikir yang terbentuk akan mendorong para siswa dalam meningkatkan kemampuan berpikir kreatif matematis. 
Dalam proses pembelajaran matematika, kemampuan berpikir kreatif sangat penting, karena dengan berpikir kreatif siswa dapat menuangkan ide-ide nya ke dalam bentuk nyata. Sedangkan Silver Sriraman ( Utari, dkk 2012) mendefinisikan kreativitas matematik sebagai kemampuan pemecah masalah dan berpikir matematik secara deduktif dan logik. Albert (Damayanti dan Sumardi, 2018) dalam tulisannya menyatakan bahwa "opinition that providing an open mathematical problem will be more useful because it requires learning by collaborating knowledge rather than learning with application problems. Sedangkan pendapat (Surya 2011) mengatakan berpikir kreatif memuat aspek keterampilan positif, efektif dan metakognitif. Keterampilan kognitif memuat kemampuan serupa dengan pengertian kreativitas sebagai proses. Berpikir kreatif dalam ranah afektif antara lain memuat: merasakan masalah dan peluang, toleran terhadap ketidakpastian, memahami lingkungan dan kekreatifan orang lain, bersifat terbuka, berani mengambil resiko, membangun rasa percaya diri, mengontrol diri, rasa ingin tau, menyatakan dan merespon perasaan dan emosi, dan mengantisipasi sesuatu yang tidak diketahui. Pengetahuan metagognitif yang termuat dalam berpikir kreatif antara lain: merancang strategi, menetapkan tujuan dan keputusan, memprediksi data yang tidak lengkap, memahami kekreatifan dan sesuatu yang tidak dipahami oleh orang lain, mengdiagnosa informasi yang tidak lengkap, membuat pertimbangan yang multifel, mengatur emosi, elaborasi mencari solusi permasalah dan rencana.

Dalam hal ini, siswa diajak untuk berpikir kreatif dalam mencari solusi. Selama ini kemampuan kreativitas siswa dalam kegiatan belajar kurang aktif, baik dalam proses tanya jawab maupun dalam menghadapi masalah matematis. Salah satu tolak ukur yang dapat digunakan dalam keberhasilan siswa terhadap pembelajaran matematika, yaitu dengan melihat rata-rata hasil tes harian yang selalu di bawah KKM. Menurut pengamatan penulis fakta menggambarkan kurang berhasilnya proses pembelajaran matematika. Seperti tampak pada tabel di bawah ini.

Tabel 1 Rata-rata nilai ulangan harian SMPN I Cikalong Kulon

\begin{tabular}{ccccc}
\hline Kelas & KKM & \multicolumn{3}{c}{ Nilai Ulangan Harian } \\
\cline { 3 - 5 } & & 1 & 2 & 3 \\
\hline VII-G & 65 & 50 & 40 & 58 \\
VII-H & 65 & 45 & 53 & 55 \\
\hline
\end{tabular}

Berdasarkan fakta tersebut, maka dibutuhkan kemampuan dan kerja keras siswa untuk mencapai nilai yang memenuhi KKM serta peranan guru sebagai fasilitator sangat 
penting, untuk itu perlu melakukan pembelajaran dengan strategi yang mendorong siswa agar memiliki kemampuan dalam berpikir kreatif matematis.

Salah satu alternatif dari permasalahan-permasalahan di atas adalah pembelajaran matematika dengan strategi Think-Talk-Write (TTW) yang diupayakan dapat membuat siswa lebih kreatif dalam proses belajar-mengajar pada mata pelajaran matematika. Melalui keleterlibatan siswa secara aktif tersebut, maka diharapkan kemampuan krativitas siswa akan dapat terlatih dengan baik. Selain itu, Think-Talk-Write (TTW) juga bisa memberikan efek positif atau negatif bagi siswa khususnya terhadap pembelajaran matematika. Huinker dan Lauhlin (dalam Himmatulafthina,dkk., 2017) ini pada dasarnya dibangun melalui berpikir, berbicara, dan menulis.

\section{METODOLOGI}

Berdasarkan latar belakang dan rumusan masalah diatas metode yang digunakan dalam penelitian ini yaitu metode penelitian eksperimen. Penelitian ini akan mengkaji tentang adakah peningkatan kemampuan kreatif matematis siswa yang mendapatkan pembelajaran dengan strategi Think-Talk-Write (TTW). Penelitian ini bertujuan untuk menganalisis peningkatan kemampuan kreatif matematis siswa yang mendapat pembelajaran dengan strategi Think-Talk-Write (TTW). dan siswa yang mendapat pembelajaran konvensional.

Sampel pada quasi experimental design tidak diambil secara acak sehingga kelemahan quasi eksperimen adalah tidak dapat sepenuhnya mengkontrol variabel-variabel luar yang dapat mempengaruhi pelaksanaan eksperimen. Implementasinya penelitian ini dilakukan pada siswa dari dua kelas dengan pendekatan pembelajaran yang berbeda. Kelompok pertama merupakan Kelompok Eksperimen yang diberikan pembelajaran dengan strategi Think-Talk-Write (TTW). Sedangkan kelompok kedua adalah Kelompok Kontrol yang memperoleh pembelajaran konvensional. Kedua kelompok tersebut diberikan pretes, selanjutnya diberikan postes yaitu tes kemampuan kreatif matematis. Penelitian ini tidak menggunakan kelas secara acak, tetapi menerima keadaan subjek apa adanya.

Desain penelitian yang digunakan dalam penelitian ini digambarkan sebagai berikut:

$\mathrm{O} \quad \mathrm{X} \quad \mathrm{O}$

Keterangan:

$\mathrm{O} O$

O: Prites/postes

X: Pembelajaran Dengan strategi TTW 
Peneliti tidak melakukan teknik acak pada kelompok subjek, maka peneliti mengusahakan pada awal observasi kedua kelompok yang digunakan sejauh mungkin sama (ekivalen). Skor prates akan dianalisis untuk menetapkan apakah kedua kelompok tersebut berbeda secara signifikan atau tidak.

Adapun populasi dalam penelitian ini adalah siswa kelas VII di sekolah SMP Negri I Cikalongkulon. Yang dijadikan sampel adalah kelas VII G sebagai Kelompok Eksperimen dan kelas VII H sebagai Kelompok Kontrol, dipilih sebanyak dua kelas dari sembilan kelas yang ada dengan penentuan sampel dilakukan dengan menggunakan teknik "Purposive Sampling“ yaitu teknik pengambilan sampel berdasarkan pertimbangan tertentu (Sugiyono, 2011). Informasi awal dalam pemilihan sampel dilakukan berdasarkan beberapa pendapat dari guru mata pelajaran matematika disekolah kelas VII pada sekolah tersebut, yang sudah mengetahui karakteristik dan kemampuan siswa pada kedua kelas tersebut, kedua kelas yang dipilih memiliki kemampuan yang setara didasarkan pada perolehan nilai matematika siswa pada semester sebelumnya.

\section{HASIL DAN PEMBAHASAN}

Tujuan utama penelitian ini adalah untuk menganalisis peningkatan kemampuan kreatif matematis siswa yang mendapatkan pembelajaran Think-Talk-Write (TTW) dan siswa yang mendapatkan pembelajaran secara konvensional. Pada penelitian ini tes dilakukan sebanyak dua kali, yaitu sebelum diberi perlakuan (pretes) dan setelah diberi perlakuan (postes). Tes ini diberikan kepada kelompok eksperimen dan kelompok kontrol. Kelompok eksperimen memperoleh pembelajaran Think-Talk-Write (TTW). Dan kelompok kontrol memperoleh pembelajaran secara konvensional. Pretes yang dimaksud adalah tes awal yang tujuannya untuk mengetahui kemampuan awal kedua kelompok yang dijadikan sampel penelitian terhadap kemampuan kreatif matematis siswa. Postes yang dimaksud adalah tes akhir yang dilaksanakan setelah kedua kelompok diberikan perlakuan, yaitu pembelajaran Think-Talk-Write (TTW) untuk kelompok eksperimen dan konvensional, untuk kelompok kontrol tujuannya untuk mengetahui apakah ada peningkatan pada kedua kelompok yang dijadikan sebagai sampel penelitian.

Berikut ini diuraikan hasil penelitian dan pembahasannya, semua data diolah dengan menggunakan bantuan program SPSS versi 22 dan MS. Excel 2010. 


\section{Pretes dan Postes Kemampuan Kreatif Matematis}

Berdasarkan hasil skor pretes dan postes pada aspek yang diukur, yaitu kemampuan kreatif matematis, diperoleh skor minimuan $\mathrm{m}\left(\mathrm{x}_{\min }\right)$, skor maksimum $\left(\mathrm{x}_{\max }\right)$ skor rerata $(\mathrm{x})$, persentase (\%), dan standar deviasi (s). Perhitungan statistik deskriptif hasil tes secara ringkas disajikan dalam tabel 2 berikut.

Tabel 2 Rekapitulasi Hasil Pretes dan Postes Kemampuan Kreatif Matematis

\begin{tabular}{|c|c|c|c|c|c|c|c|c|c|c|c|c|}
\hline \multirow{2}{*}{ Kelompok } & \multirow{2}{*}{ Data } & \multirow{2}{*}{$\begin{array}{l}\text { Skor } \\
\text { Ideal }\end{array}$} & \multicolumn{5}{|c|}{ Pretes } & \multicolumn{5}{|c|}{ Postes } \\
\hline & & & $\mathrm{X}_{\min }$ & $\mathrm{X}_{\max }$ & $\bar{x}$ & $\%$ & $\mathrm{~s}$ & $\mathrm{X}_{\min }$ & $\mathrm{X}_{\max }$ & $\bar{x}$ & $\%$ & $\mathrm{~s}$ \\
\hline Eksperimen & 39 & 16 & 0 & 9 & 2,59 & 0,26 & 2,22 & 2 & 16 & 7 & 0,70 & 4,03 \\
\hline Kontrol & 39 & 16 & 0 & 6 & 1,87 & 0,19 & 1,67 & 0 & 14 & 6,3 & 0,63 & 3,39 \\
\hline
\end{tabular}

Pada tabel 2 diperlihatkan bahwa rata-rata nilai pretes atau-sebelum diberikan perlakuan kemampuan berpikir kreatif matematis kelompok eksperimen adalah 2,59 dan kelompok kontrol adalah 1,87. Perbedaan nilai rata-rata kedua kelompok adalah 0,72. Kemudian setelah diberi perlakuan, diberikan postes untuk kelompok eksperimen memiliki nilai rata-rata 7,03 dan kelompok kontrol memiliki nilai eata-rata 6,28. Perbedaan nilai ratarata kedua kelompok adalah 0,75 . Terlihat bahwa peningkatan nilai rata-rata kelompok eksperimen setelah diberi perlakuan dengan strategi Think-Talk-Write (TTW) lebih tinggi dari kemampuan nilai pretes.

Berikut secara ringkas disajikan rerata pretes dan postes kemampuan berpikir kreatif matematis pada tabel 3 berikut.

Tabel 3 Rerata Pretes dan Postes Kemampuan Berpikir Kreatif

\begin{tabular}{ccc}
\hline Kelompok & Pretes & Postes \\
\hline Eksperimen & 2,595 & 7,03 \\
Kontrol & 1,870 & 6,28 \\
\hline
\end{tabular}

Untuk memperjelas hasil perhitungan tersebut, maka rerata pretes dan postes disajikan dalam bentuk diagram batang pada gambar1

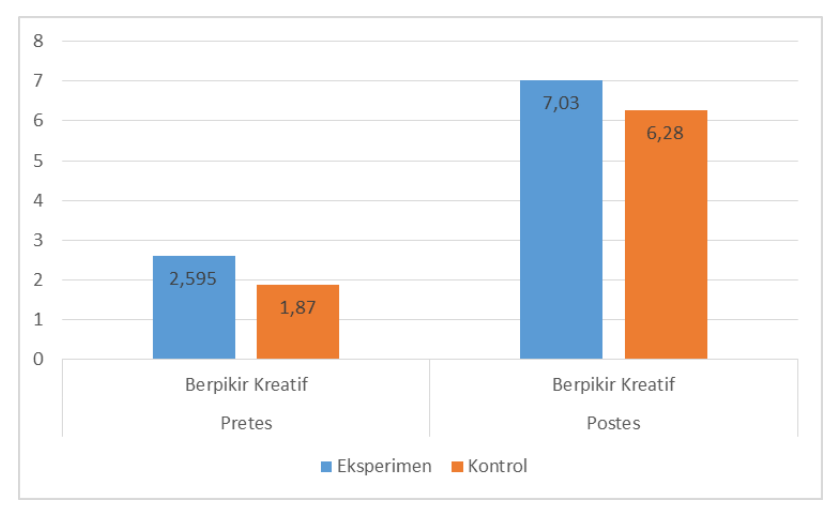

Gambar 1 Rerata Pretes dan Postes Kemampuan Berpikir Kreatif Kelompok Eksperimen dan Kelompok Kontrol 
Dari tabel 3 dan gambar 1 terlihat bahwa rerata nilai postest Kemampuan Kreatif Matematis siswa kelompok eksperimen yang mendapat pembelajaran Think-Talk-Write (TTW) menunjukkan hasil yang lebih tinggi dibandingkan kelompok kontrol yang menggunakan pembelajaran secara konvensional.

Untuk mengetahui apakah perbedaan peningkatan. Kemampuan Kreatif Matematis siswa antara kelompok eksperimen dan kelompok kontrol berbeda secara signifikan perlu dilakukan uji perbedaan dua rerata.

Tabel 4 Rerata dan Standar Deviasi Gain Kemampuan Kreatif Matematis

\begin{tabular}{llccl}
\hline Kelompok & $\mathrm{N}$ & $\bar{x}$ & $\mathrm{~S}$ & Kualifikasi \\
\hline Eksperimen & 39 & 0,0449 & 0,03626 & Sedang \\
Kontrol & 39 & 0,0444 & 0,02732 & Sedang \\
\hline
\end{tabular}

Untuk melihat peningkatan Kemampuan Kreatif Matematis yang telah dicapai oleh siswa dan kualifikasinya digunakan data gain ternormalisasi. Rerata gain ternormalisasi merupakan gambaran peningkatan Kemampuan Kreatif Matematis siswa baik dengan pembelajaran Think-Talk-Write (TTW) maupun dengan pendekatan konvensional, disajikan pada Tabel 4.

Untuk lebih jelasnya hasil perhitungan tersebut data dapat disajikan dalam diagram batang pada gambar 2 berikut ini:

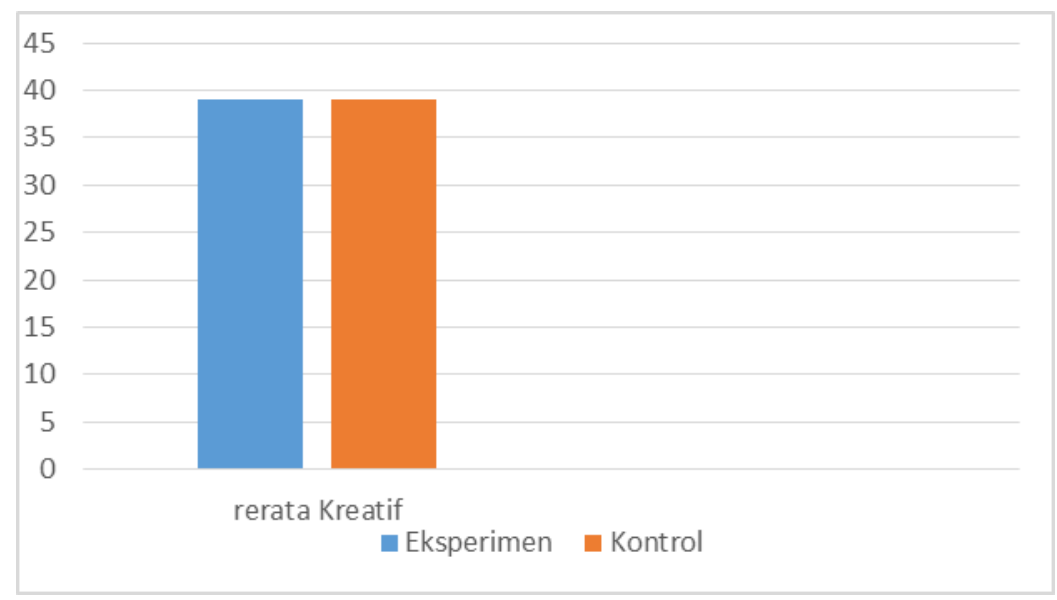

Gambar 2 Rata-rata Gain Kemampuan Kreatif Matematis

Dari tabel 4 dan gambar 2 terlihat bahwa siswa yang proses pembelajaraanya menggunakan Think-Talk-Write (TTW) untuk kelompok eksperimen memiliki rata-rata gain lebih tinggi dari pada siswa yang pembelajaraan nya secara konvensional yaitu 
kelompok kontrol. Walapun kualifikasi gain kelompok eksperimen dan kualifikasi gain kelompok kontrol pada kemampuan Berpiki Kreatif hampir sama tetapi ada perbedaan walaupun hanya 0,005. Standar deviasi untuk kelompok eksperimen relatif lebih besar daripada kelompok kontrol. Hal ini menunjukan bahwa peningkatan kemampuan berpikir kreatif siswa kelompok kontrol.

\section{Perhitungan uji perbedaan dua rerata gain}

Perhitungan uji perbedaan dua rerata gain dilakukan dengan bantuan program spss versi 22 pada taraf signifikansi $\alpha=0.05$ dapat dilihat pada lampiran $M$, sedangkan rangkumanya disajikan pada tabel 3.6 berikut :

Tabel 5 Uji Perbadaan Rerata Gain Kemampuan Berpikir Kratif Matematis

\section{Paired Differences}

\begin{tabular}{|c|c|c|c|c|c|c|c|c|c|}
\hline & & \multirow[b]{2}{*}{ Mean } & \multirow[b]{2}{*}{$\begin{array}{c}\text { Std. } \\
\text { Deviatiaon }\end{array}$} & \multirow{2}{*}{$\begin{array}{l}\text { Std. } \\
\text { Error } \\
\text { Mean } \\
\end{array}$} & \multicolumn{2}{|c|}{$\begin{array}{l}\text { 95\% Confidence } \\
\text { Interval of the } \\
\text { Difference }\end{array}$} & \multirow[b]{2}{*}{$T$} & \multirow[b]{2}{*}{$d f$} & \multirow[b]{2}{*}{$\begin{array}{l}\text { Sig. (2- } \\
\text { tailed) }\end{array}$} \\
\hline & & & & & Lower & Upper & & & \\
\hline $\begin{array}{c}\text { Pair } \\
1\end{array}$ & $\begin{array}{c}\text { Kontrol } \\
\text { Eksperimen }\end{array}$ & 1,46590 & 0,50666 & 0,05737 & 1,35166 & 1,58013 & 25,552 & 77 & .000 \\
\hline
\end{tabular}

Dari tabel 5 di peroleh $\rho$-value (Sig) perbedaan rerata peningkatan kemampuan berpikir kreatif matematis siswa kelompok eksperimen dan siswa kelompok kontrol adalah 0.000. Nilai signifikansi tersebut lebih kecil dari taraf signifikansi $(\alpha) 0.05$ maka $H_{0}$ ditolak. Sehingga dapat disimpulkan bahwa peningkatan kemampuan berpikir kreatif matematis siswa yang memperoleh pembelajaran Think-Talk-Write (TTW) lebih tinggi secara signifikansi dari pada peningkatan kemampuan berpikir kreatif matematis siswa yang memperoleh pembelajaran konvensional pada taraf $(\alpha) 0.05$.

\section{Hasil Skala Sikap}

Setelah pelaksanaan postest kemampuan kreatif, angket disebarkan untuk memperoleh tentang sikap siswa terhadap pembelajaran Think-Talk-Write (TTW) aspek yang termuat dalam angket ada empat, pertama adalah untuk mengetahui sikap siswa terhadap pelajaran matematika, kedua untuk mengetahui sikap siswa tentang pembelajaran kelompok, ketiga untuk mengetahui sikap siswa terhadap alat peraga matematika, keempat untuk mengetahui sikap siswa terhadap model Think-Talk-Write (TTW). Penskoran terhadap skala sikap siswa dilakukan secara statistika. Hasil analisis angket skala sikap siswa terhadap pembelajaran TTW diambil dari pembobotan skor skala sikap. Secara umum hasil analisis 
skala sikap siswa digambarkan pada tabel 6 berikut.

Tabel 6 Rekapitulasi Hasil Pengukuran Skala Sikap Kelas Eksperimen dan Kelas Kontrol

\begin{tabular}{lcc}
\hline \multirow{2}{*}{ Indikator } & \multicolumn{2}{c}{ Kelas Eksperimen } \\
\cline { 2 - 3 } & Rerata skor & Interprestasi \\
\hline Sikap siswa terhadap pelajaran matematika & 3,71 & Positif \\
Sikap siswa terhadap pembelajaran & 4,59 & Positif \\
kelompok & 3,99 & Positif \\
Sikap siswa terhadap alat peraga & 3,59 & Positif \\
$\begin{array}{l}\text { Sikap peserta didik terhadap model } \\
\text { pembelajaran TTW }\end{array}$ & & \\
\hline
\end{tabular}

\section{KESIMPULAN}

Berdasarkan hasil penelitian dan pembahasan mengenai peningkatan kemampuan kreatif matematis dengan pembelajaran strategi Think-Talk-Write (TTW) mengalami peningkatan yang lebih baik dibandingkan dengan siswa yang mendapat pembelajaran konvensional, meskipun perbedaan tersebut kurang signifikan. Itu dikarenakan kondisi siswa di setiap kelas terlalu banyak. Dengan demikian pembelajaran yang menggunakan strategi Think-Talk-Write (TTW) dapat meningkatkan kemampuan kreatif matematis siswa. Sikap siswa terhadap strategi Think-Talk-Write (TTW) positif.

\section{REKOMENDASI}

Dari hasil penelitian mengenai pembelajaran matematika dengan menggunakan strategi Think-Talk-Write (TTW), diantaranya dapat diterapkan diberbagai jenjang, baik SD, SMP maupun SMA. Dengan Penerapan strategi Think-Talk-Write (TTW) juga dapat mengubah paradigma lama, dimana pendidik sebagai pusat pembelajaran menjadi siswa yang menjadi sebagai pusat pembelajaran, dan pendidik hanya sebagai motivator dan fasilitator.

Pembelajaran matematika dengan pendekatan strategi Think-Talk-Write (TTW) baik juga diterapkan pada pokok bahasan yang lain. Model pembelajaran dengan strategi Think-Talk-Write (TTW) memerlukan waktu yang lebih lama dari pembelajaran biasa (konvensional). Jadi disarankan pembelajaran dengan strategi Think-Talk-Write (TTW) diterapkan pada topik-topik matematika yang esensial sehingga siswa dapat menerapkan pengetahuan dan prosedur matematika yang telah mereka pelajari. aspek kemampuan matematis yang diukur hanya kemampuan kreatif matematis dan berpikir kreatif. Penelitian selanjutnya dapat lebih mengembangkan penelitiannya pada aspek kemampuan matematis lainnya. 
DAFTAR PUSTAKA

Damayanti, T. N. Sumardi. (2018). Mathematical Creative Thinking Ability of Juniro High School Srudents in Solving Open-Ended Problem. Journal of Research and Advances in Mathematics Education: Universitas Muhammadiyah Surakarta Vol.3. No.1, pp 36-45. ISSN: 2503-3697, e-ISSN: 2541-2590

Duwi Priyatno. (2014). SPSS 22 Pengolah Data Terpraktis. ANDI: Yogyakarta

Himmatulafthina, dkk. (2017). The Comparison of Think Talk Write and Think Pair Share Model whith Realistic Mathematics Education Approach Viewed from Mathematical-Logical Intelligence. International Journal of Science and Applied Science: Sebelas Maret University. Vol.2 No.1 (2017). P-ISSN: 2549-4635. E-ISSN: $2549-4627$

Ms. Exel 2020

Sugiyono, (2011). Metode Penelitian Kualitatif, Kuantitatif dan $R \&$ D. Bandung: Alfabeta

Sumarmo, Utari. dkk. (2012). Kemampuan Dan Disposisi Berpikir Logis, Kritis, Dan Kreatif Matematik. Jurnal Pengajaran MIPA Vol. 17 Nomor 1.

Surya, H. (2011). Strategi Jitu mencapai Kesuksesan Belajar. Jakarta: PT. Elex Media Komputindo

Undang-undang Sistem Pendidikan Nasional Nomor 20 Tahun 2003. Jakarta: Fokus Media 